\title{
The Effect of Age on von Willebrand Factor and Bleeding Symptoms in von Willebrand Disease
}

\author{
Craig D. Seaman ${ }^{1,2}$ Margaret V. Ragni,2® \\ ${ }^{1}$ Division of Hematology/Oncology, Department of Medicine, \\ University of Pittsburgh Medical Center, Pittsburgh, Pennsylvania, \\ United States \\ ${ }^{2}$ Hemophilia Center of Western Pennsylvania, Pittsburgh, \\ Pennsylvania, United States \\ Thromb Haemost 2020;120:1159-1165.
}

\begin{abstract}
Address for correspondence Craig D. Seaman, MD, Division of Hematology/Oncology, University of Pittsburgh, 3636 Boulevard of the Allies, Pittsburgh, PA 15213-4306, United States

(e-mail: seamanc@upmc.edu).
\end{abstract}

\begin{abstract}
Keywords

- von Willebrand disease

- von Willebrand factor

- age

- bleeding score

von Willebrand disease (VWD) is a quantitative or qualitative defect in von Willebrand factor (VWF) resulting in mucocutaneous bleeding symptoms and hemorrhage following hemostatic challenges, such as trauma or surgery. VWD-specific therapy, DDAVP (1-desamino-8$D$-arginine vasopressin) and VWF concentrates, is necessary periprocedurally to ensure adequate hemostasis. The aging VWD patient may complicate this matter. The plasma concentration of many coagulation proteins, including VWF, increases with age. While it has been established that VWF levels increase with age in a healthy population, emerging research demonstrates this occurs in certain subtypes of $\mathrm{VWD}$, too. Thus, the management of periprocedural VWD-specific therapy in the aging VWD patient is problematic when VWF levels increase over time to normal, and hematologists are left with uncertainty regarding whether or not periprocedural VWD-specific therapy is still necessary. In this article, we will review the current state of the literature regarding the effect of age on VWF levels in the healthy population and VWD while exploring possible etiologies for this phenomenon. Further, we will detail how this affects bleeding symptoms and highlight what research remains to be done to optimize care in this patient population.
\end{abstract}

\section{Introduction}

von Willebrand disease (VWD) is a quantitative or qualitative defect in von Willebrand factor (VWF). It is the most common inherited bleeding disorder and is estimated to affect up to $1 \%$ of the population, although the symptomatic prevalence if $10-$ fold less. ${ }^{1}$ Bleeding manifestations are often mucocutaneous, and excessive bleeding occurs with hemostatic challenges, such as invasive procedures and surgery. ${ }^{2}$ The severity of disease is assessed with the use of bleeding assessment tools (BATs), which provide an objective measure of bleeding symptoms. ${ }^{3,4}$ Bleeding symptoms are treated with DDAVP (1-desamino-8-D-arginine vasopressin) and VWF concentrates. In addition, VWD-specific therapy is necessary periprocedurally to ensure adequate hemostasis. ${ }^{5}$

received

April 17, 2020

accepted after revision

May 15, 2020

The management of periprocedural VWD-specific therapy is sometimes problematic in older patients. The plasma concentration of many coagulation proteins, including VWF, increases with age. While it has been established that VWF levels increase with age in a healthy population, emerging research demonstrates this occurs in certain subtypes of VWD, too. When VWF levels increase over time to normal (i.e., VWF: antigen $[\mathrm{Ag}]$ greater than or equal to $0.50 \mathrm{IU} / \mathrm{mL}$ ), hematologists are faced with the dilemma whether or not VWF-specific therapy is indicated at the time of surgery. If VWD patients with normalized VWF levels are no longer at an increased risk of bleeding then periprocedural VWD-specific therapy may lead to thrombotic complications, especially given the increased risk of cardiovascular disease in older patients; thus, should be omitted. In this article, we will review the current

(c) 2020 Georg Thieme Verlag KG Stuttgart · New York
DOI https://doi.org/ 10.1055/s-0040-1713636. ISSN 0340-6245. 
state of the literature regarding this topic to identify what is known and what research remains to be done to optimize care in this patient population.

\section{Clinical Vignette}

A 67-year-old female presents to clinic for preoperative hematology clearance. She has a history of DDAVP-responsive type $1 \mathrm{VWD}$, and she is scheduled to undergo a laparoscopic sigmoid colectomy for recurrent diverticulitis. She has not been seen in the clinic for more than 20 years. Her lowest recorded VWF:Ag level and VWF:ristocetin cofactor (RCo) activity were 0.41 and $0.38 \mathrm{IU} / \mathrm{mL}$, respectively, more than 30 years ago. Her lifelong bleeding score determined with the condensed molecular and clinical markers for the diagnosis and management of type 1 (MCMDM-1) BAT is 7 based on a history of easy bruising, epistaxis, menorrhagia requiring estrogen containing hormonal therapy, and excessive bleeding following wisdom teeth extraction. She denies any recent bleeding symptoms in the past several years; however, she is postmenopausal and has not required any invasive procedures during that time. VWF levels are repeated, and the VWF: $\mathrm{Ag}$ level is $0.95 \mathrm{IU} / \mathrm{mL}$, and the VWF:RCo activity is $0.90 \mathrm{IU} / \mathrm{mL}$. Factor VIII(FVIII) activity is $1.61 \mathrm{IU} / \mathrm{mL}$. She is not receiving any exogenous estrogen therapy. Other pertinent medical history includes hypertension, type II diabetes mellitus, obesity, and remote tobacco abuse. Is VWD-specific therapy necessary perioperatively, and if so, what are the specific dosing recommendations?

\section{Effect of Age on von Willebrand Factor in the General Population}

The plasma concentration of many coagulation proteins, including fibrinogen, FVII, FVIII, FIX, and FXII, increases with age. Correspondingly, markers of coagulation activation, prothrombin fragment $1+2$, thrombin-antithrombin III complex, and D-dimer, are elevated. ${ }^{6}$ Similarly, VWF levels increase with age. VWF is an acute phase reactant: $35 \%$ of the variability in VWF levels is explained by environmental (cigarette smoke), physiological (hormonal, exercise, and age), and pathological (inflammation, atherosclerosis, and liver disease) factors, the incidence of which are increased in older adults. ${ }^{7}$ An Italian prospective study compared 74 centenarians and 110 controls (55 less than 45 years of age), excluding chronic disorders (malignancy, diabetes, cardiovascular, kidney disease, etc.) and reported VWF:Ag levels were significantly higher among centenarians. VWF: Ag levels were $0.77,0.99$, and 2.45 among $O$ blood group and $1.15,1.52$, and 2.85 among non-O blood group younger controls (less than 45 years of age), older controls ( 45 years of age or older), and centenarians, respectively. Interestingly, using a laboratory database-established cut-off value of $17 \%$, the proportion of individuals with a reduction in high molecular weight multimers (HMWM) was $0 \%$ in younger controls, $25 \%$ in older controls, and $51 \%$ in centenarians. ${ }^{8}$ HMWMs are the most hemostatically active multimers. A decrease in the proportion of HMWMs present may counter- act any increase in coagulation activity seen with rising VWF levels. A cross-sectional study of 123 women showed that VWF:Ag levels and VWF:RCo activity increased by an average of 0.17 and $0.15 \mathrm{IU} / \mathrm{mL}$, respectively, per decade of life. ${ }^{9}$ This is counterintuitive to the expectation that the decline in estrogen in postmenopausal females is paralleled by a reduction in VWF levels. Recently, a cross-sectional study of 207 patients showed increasing VWF levels with age is greatly influenced by ABO blood type. ${ }^{10}$ Elderly individuals (age 55-87) with blood type 0 were observed to have a 1.25fold increase in mean VWF:Ag levels, $1.68 \pm 0.62$ versus $0.98 \pm 0.32 \mathrm{IU} / \mathrm{mL}, p<0.001$, compared with young individuals (age 1-17). Whereas, elderly individuals with blood type non-O demonstrated a 1.71-fold increase in mean VWF:Ag levels, $0.85 \pm 0.25$ versus $1.11 \pm 0.38 \mathrm{IU} / \mathrm{mL}, p=0.002$, compared with young individuals. This suggests $A B O$, and possibly other non-VWF loci, contribute to age-related changes in VWF levels. Finally, when interpreting the results of studies investigating changes in VWF levels, it is important to keep in mind that VWF assays may not be completely reliable and have demonstrated an interlaboratory coefficient of variation as high as $30 \%{ }^{11}$

\section{Effect of Age on von Willebrand Factor in von Willebrand Disease}

While it has been established that VWF levels increase with age in a healthy population, emerging research demonstrates this occurs in VWD, too, and has been described in several observational studies (-Table 1). A Canadian retrospective cohort study of 31 patients with type 1 VWD (historical VWF: Ag level and/or VWF:RCo activity less than $0.50 \mathrm{IU} / \mathrm{mL}$ ) reported VWF:Ag levels and VWF:RCo activity increased by $0.30 \mathrm{IU} / \mathrm{mL}$ (95\% confidence interval [CI], 0.21-0.39) and $0.20 \mathrm{IU} / \mathrm{mL}$ (95\% CI, 0.13-0.27), respectively, per decade. ${ }^{12}$ The average duration of follow-up was 11 years, and during this time, the mean VWF:Ag level increased from 0.44 to $0.71 \mathrm{IU} / \mathrm{mL}, p<0.001$, and the mean VWF:RCo activity increased from 0.34 to $0.56 \mathrm{IU} / \mathrm{mL}, p<0.001$. In all, $58 \%$ of the patients had VWF:Ag levels and VWF:RCo activity that increased into the normal range. A similar retrospective cohort study looked at the relationship between age and VWF levels in 126 patients with a diagnosis of type 1 VWD (historical VWF:Ag level and/or VWF RCo activity less than $0.30 \mathrm{IU} / \mathrm{mL}$ ) or "low VWF" (historical VWF:Ag level and/or VWF:RCo activity $0.30-0.49 \mathrm{IU} / \mathrm{mL}) .^{13} \mathrm{VWF}$ :Ag levels and VWF:RCo activity increased 0.024 and $0.014 \mathrm{IU} / \mathrm{mL}$, $p<0.001$ each, respectively, per year. The average duration of follow-up was 10.5 years. Normalization of VWF:Ag levels and VWF:RCo activity occurred in $27.8 \%$ of patients. A third retrospective cohort study of 195 patients with type 1 VWD demonstrated a $0.14 \pm 0.033$ and $0.096 \pm 0.02 \mathrm{IU} / \mathrm{mL}$, $p<0.05$ each, increase in mean VWF:Ag levels and VWF: RCo activity, respectively, between the first and last measurements during a 6.6-year median duration of follow-up. ${ }^{14}$ In a subgroup analysis of 143 patients with mild disease (VWF:Ag level and VWF:RCo activity $0.30-0.49 \mathrm{IU} / \mathrm{mL}$ ) and 52 patients with moderate to severe disease (VWF:Ag level 
Table 1 Effect of age on von Willebrand factor in von Willebrand disease

\begin{tabular}{|c|c|c|c|}
\hline Study type & Author & Patient population & Results \\
\hline \multirow[t]{3}{*}{$\begin{array}{l}\text { Retrospective } \\
\text { cohort study }\end{array}$} & $\begin{array}{l}\text { Rydz et al } \\
\text { Canada }\end{array}$ & $\begin{array}{l}31 \text { patients with type } 1 \text { VWD (historical } \\
\text { VWF:Ag level and/or VWF:RCo activity less } \\
\text { than } 0.50 \mathrm{IU} / \mathrm{mL} \text { ) } \\
\text { Mean age at last observation } 46 \text { years } \\
\text { (range } 30-74 \mathrm{y} \text { ) }\end{array}$ & $\begin{array}{l}\text { VWF:Ag levels increased } 0.30 \mathrm{IU} / \mathrm{mL} \\
(95 \% \mathrm{Cl}, 0.21-0.39) \text { per decade } \\
\text { Mean VWF:Ag level increased from } 0.44 \text { to } \\
0.71 \mathrm{IU} / \mathrm{mL}, p<0.001 \text {, over an average } \\
\text { duration of follow-up of } 11 \text { years } \\
\text { VWF:Ag levels increased into the normal } \\
\text { range in } 58 \% \text { of patients }\end{array}$ \\
\hline & $\begin{array}{l}\text { Abou-Ismail et al } \\
\text { United States }\end{array}$ & $\begin{array}{l}126 \text { patients with type } 1 \text { VWD (historical } \\
\text { VWF:Ag level and/or VWF:RCo activity less } \\
\text { than } 0.30 \mathrm{IU} / \mathrm{mL} \text { ) or "low VWF" (historical } \\
\text { VWF:Ag level and/or VWF:RCo activity } \\
0.30-0.49 \mathrm{IU} / \mathrm{mL} \text { ) } \\
\text { Mean age at last observation } 43.5 \pm 21.5 \\
\text { years }\end{array}$ & $\begin{array}{l}\text { VWF:Ag levels increased } 0.024 \mathrm{IU} / \mathrm{mL} \text {, } \\
p<0.001 \text {, per year } \\
\text { VWF:Ag levels normalized in } 27.8 \% \text { of } \\
\text { patients during an average duration of } \\
\text { follow-up of } 10.5 \text { years }\end{array}$ \\
\hline & $\begin{array}{l}\text { Borghi et al } \\
\text { Italy }\end{array}$ & $\begin{array}{l}143 \text { patients with mild type } 1 \text { VWD disease } \\
\text { (VWF:Ag level and VWF:RCo activity } \\
0.30-0.49 \mathrm{IU} / \mathrm{mL} \text { ) and } 52 \text { patients with } \\
\text { moderate to severe type } 1 \text { VWD (VWF:Ag } \\
\text { level and VWF:RCo activity less than } \\
0.30 \mathrm{IU} / \mathrm{mL} \text { ) } \\
\text { Mean age at first observation } 28.7 \mathrm{y} \\
\text { (range } 0.4-74.5 \mathrm{y} \text { ) }\end{array}$ & $\begin{array}{l}\text { VWF:Ag levels increased } 0.14 \pm 0.033- \\
\mathrm{IU} / \mathrm{mL}, p<0.05 \text {, between the first and last } \\
\text { measurements during a } 6.6 \text {-year median } \\
\text { duration of follow-up } \\
\text { VWF:Ag levels did not increase in patients } \\
\text { with moderate to severe type } 1 \mathrm{VWD} \\
\text { VWF:Ag levels normalized in } 94 \% \text { of } \\
\text { patients with mild type } 1 \mathrm{VWD} \text { compared } \\
\text { with } 6 \% \text { of patients with moderate to } \\
\text { severe type } 1 \mathrm{VWD}\end{array}$ \\
\hline \multirow[t]{3}{*}{$\begin{array}{l}\text { Cross-sectional } \\
\text { study }\end{array}$} & $\begin{array}{l}\text { Sanders et al } \\
\text { Netherlands }\end{array}$ & $\begin{array}{l}664 \text { patients with moderate to severe VWD } \\
\text { (historical VWF:Ag level and/or VWF:RCo } \\
\text { activity less than } 0.30 \mathrm{IU} / \mathrm{mL} \text { ) } \\
\text { Mean age } 71 \text { years (range } 65-85 \text { ) in } \\
\text { patients } 65 \text { years of age and older and } \\
43 \text { years (range } 16-64 \text { ) in patients less } \\
\text { than } 65 \text { years of age }\end{array}$ & $\begin{array}{l}\text { VWF:Ag levels were higher among } 71 \mathrm{VWD} \\
\text { patients } 65 \text { years of age and older com- } \\
\text { pared with } 593 \text { VWD patients less than } \\
65 \text { years of age, } 0.38 \text { and } 0.30 \mathrm{IU} / \mathrm{mL} \text {, } \\
p=0.033 \\
\text { VWF:Ag levels increased } 0.035 \mathrm{IU} / \mathrm{mL}(95 \% \\
\mathrm{Cl},-0.6 \text { to } 7.6) \text { per decade among } 40 \\
\text { patients, age } 65 \text { or older, with type } 1 \mathrm{VWD} \\
\text { VWF:Ag levels did not increase among } 26 \\
\text { patients, age } 65 \text { or older, with type } 1 \mathrm{VWD}\end{array}$ \\
\hline & $\begin{array}{l}\text { Flood et al } \\
\text { United States }\end{array}$ & $\begin{array}{l}310 \text { patients with a historical diagnosis of } \\
\text { type } 1 \text { VWD }\end{array}$ & $\begin{array}{l}172 \text { of } 310(36 \%) \text { patients with a historical } \\
\text { diagnosis of type } 1 \text { VWD had normal VWF: } \\
\text { Ag levels when repeated at enrollment } \\
\text { (median VWF:Ag level was } 0.76 \mathrm{IU} / \mathrm{mL} \text { ) }\end{array}$ \\
\hline & $\begin{array}{l}\text { Atiq et al } \\
\text { Netherlands }\end{array}$ & $\begin{array}{l}333 \text { patients with type } 1 \text { VWD. } \\
\text { Mean age } 47 \pm 15 \text { years }\end{array}$ & $\begin{array}{l}\text { VWF:Ag levels increased } 0.03 \mathrm{IU} / \mathrm{mL} \\
(95 \% \mathrm{Cl}, 0.01-0.04) \text { per decade } \\
\text { VWF:Ag levels increased from } 0.36 \mathrm{IU} / \mathrm{mL} \\
(95 \% \mathrm{Cl}, 0.23-0.49) \text { in patients without } \\
\text { comorbidities to } 0.44 \mathrm{IU} / \mathrm{mL}(95 \% \mathrm{Cl} \text {, } \\
0.29-0.62) \text { in patients with one comor- } \\
\text { bidity to } 0.67 \mathrm{IU} / \mathrm{mL}(95 \% \mathrm{Cl}, 0.39-0.90) \text { in } \\
\text { patients with two comorbidities }\end{array}$ \\
\hline
\end{tabular}

Abbreviations: $\mathrm{Cl}$, confidence interval; VWD, von Willebrand disease; VWF:Ag, von Willebrand factor:antigen; VWF:RCo, von Willebrand factor: ristocetin cofactor.

and VWF:RCo activity less than $0.30 \mathrm{IU} / \mathrm{mL}$ ), an increase in VWF levels was restricted to those with mild disease. Among patients with mild disease, 94\% experienced normalization of VWF:Ag levels and VWF:RCo activity at last follow-up compared with only $6 \%$ of patients with moderate to severe disease.

In contrast to the previously described retrospective studies, the Willebrand in the Netherlands (WiN) study was a crosssectional study of patients with moderate to severe VWD (historical VWF:Ag level and/or VWF:RCo activity less than
$0.30 \mathrm{IU} / \mathrm{mL}$ ). Sanders et al reported VWF:Ag level and VWF:RCo activity per decade age increases of $0.035 \mathrm{IU} / \mathrm{mL}(95 \% \mathrm{CI},-0.6$ to 7.6) and $0.095 \mathrm{IU} / \mathrm{mL}(95 \% \mathrm{CI}, 3.7-15.3)$, respectively, among 40 elderly patients, age 65 or older, with type 1 VWD. ${ }^{15}$ There was no age-related increase in VWF levels among 26 elderly patients with type 2 VWD: VWF:Ag level $-1.6 \mathrm{IU} / \mathrm{mL}$ (95\% CI, -10.3 to 7.2 ) and VWF: RCo $0.5 \mathrm{IU} / \mathrm{mL}(95 \% \mathrm{CI},-2.8$ to 3.7). In the same study, VWF:Ag levels were higher among 71 VWD patients 65 years of age and older compared with 593 VWD patients less than 65 years of age, 0.38 and $0.30 \mathrm{IU} / \mathrm{mL}$, 
$p=0.033$. A similar large multicenter study in the United States, the Zimmerman Program, enrolled patients with an institutional diagnosis of VWD. ${ }^{16} \mathrm{VWF}$ levels were repeated at the time of enrollment, and 172 of 310 (36\%) patients with a historical diagnosis of type 1 VWD had normal VWF levels. The median VWF:Ag level was $0.76 \mathrm{IU} / \mathrm{mL}$, and the median VWF: RCo activity was $0.72 \mathrm{IU} / \mathrm{mL}$.

The above findings indicate that VWF levels increase with age, and this increase may be restricted to patients with "low VWF" and type 1 VWD; however, the reasons for both are unclear. One reason for increasing VWF levels with age is the presence of comorbid illnesses. As mentioned previously, VWF is an acute phase reactant, and $35 \%$ of the variability of VWF levels is related to external factors, such as inflammation and other related conditions. Atiq et al explored this matter in the WiN study. ${ }^{17}$ Among 333 patients with type 1 VWD, hypertension, diabetes mellitus, cancer, and thyroid dysfunction were found to be associated with increased VWF levels. Further, as the number of comorbidities increased, so did VWF levels: VWF:Ag levels increased from $0.36 \mathrm{IU} / \mathrm{mL}$ (95\% CI, 0.23-0.49) in patients without comorbidities to $0.44 \mathrm{IU} / \mathrm{mL}$ (95\% CI, 0.29-0.62) in patients with one comorbidity to $0.67 \mathrm{IU} / \mathrm{mL}(95 \% \mathrm{CI}, 0.39-0.90)$ in patients with two comorbidities. In the study, VWF:Ag levels and VWF:RCo activity increased $0.03 \mathrm{IU} / \mathrm{mL}(95 \% \mathrm{CI}, 0.01-0.04)$ and 0.04 $\mathrm{IU} / \mathrm{mL}(95 \% \mathrm{CI}, 0.02-0.06)$, respectively, per decade. Following adjustment for comorbidities, the age-related increase in VWF levels was no longer observed. Future studies exploring the effect of inflammatory biomarkers, such as C-reactive protein, on VWF levels in the context of comorbidities is needed.

The variability in VWF levels with age may be limited to those with type $1 \mathrm{VWD}$, based on the presence or absence of a VWF mutation. Pathogenic VWF gene mutations have been identified in most cases of types 2 and $3 \mathrm{VWD}$, and several large population studies have identified VWF mutations in approximately $65 \%$ of type $1 \mathrm{VWD}$ cases, which occur with greater frequency in more severe disease. ${ }^{1,18,19}$ It is proposed that the presence of VWF mutations, and associated defects in VWF synthesis and processing, prevent age-related increases in VWF levels in severe type 1 and types 2 and 3 VWD. Alternatively, it is surmised that age-related increases in VWF levels are most commonly experienced in individuals without VWF mutations, which typically occurs in patients with mild type 1 VWD, or "low VWF" (VWF:Ag level 0.30-$0.50 \mathrm{IU} / \mathrm{mL}$ ), where the decrease in VWF levels is probably explained by the effect of non-VWF genetic loci on VWF secretion, clearance, and glycosylation. Heritability accounts for approximately $65 \%$ of the variability in VWF levels with $5 \%$ of heritability explained by the VWF gene and non-VWF genetic loci responsible for the remainder, including the $A B O$ locus, which accounts for $25 \%$ of variability in VWF levels, CLEC4M, STAB2, and STXBP5, among others. ${ }^{20}$ Hence, VWF mutations correlate with the severity of disease, and if the presence of such determines whether or not an age-related increase in VWF levels is experienced, this may afford hematologists a way to predict which patients with type 1 VWD will experience an increase in VWF levels with age.

\section{Effect of Age on Bleeding Symptoms in von Willebrand Disease}

Whether or not an age-related increase in VWF levels results in reduced bleeding in VWD is uncertain. An estrogenrelated increase in VWF levels during hormonal therapy or pregnancy improves bleeding symptoms, and increasing VWF levels with DDAVP prevents periprocedural bleeding; however, it is hypothesized greater than normal VWF levels may be necessary for adequate hemostasis with aging, so normalization of VWF levels may not necessarily result in reduced bleeding. ${ }^{21}$ This issue has been explored in a few studies (-Table $\mathbf{2}$ ).

The multicenter, prospective MCMDM-1 VWD study in Europe enrolled patients with an institutional diagnosis of type 1 VWD. ${ }^{22}$ There was no specific VWF level identified for inclusion in the study; however, the median VWF:Ag level and VWF:RCo activity were 0.33 and $0.34 \mathrm{IU} / \mathrm{mL}$, respectively, in 144 index cases, and 0.36 and $0.35 \mathrm{IU} / \mathrm{mL}$, respectively, in 273 affected family members. The median VWF:Ag level and VWF:RCo activity were normal in unaffected family members and controls. The study demonstrated a trend for increasing bleeding score with age in index cases and affected family members, but not unaffected family members or controls, using the expert-administered MCMDM-1 VWD BAT at the time of diagnosis. Also, the study showed the existence of a strong inverse relationship between bleeding score and VWF levels, $p<0.001$. In contrast, in the previously discussed Zimmerman Program, using the expert-administered International Society on Thrombosis and Haemostasis BAT, Flood et al found no correlation between VWF:Ag levels and bleeding score in patients with type $1 \mathrm{VWD}$, although $24 \%$ of patients had a normal bleeding score. ${ }^{16}$

In the previously discussed WiN study, using the MCMDM-1 VWD BAT, Sanders et al found no difference in the median bleeding score between elderly VWD patients, 65 years of age and older, and younger VWD patients, less than 65 years of age, 12 versus $11, p=0.154$, respectively. ${ }^{15}$ Nor was there any difference in the median bleeding score when the two groups were compared separately according to VWD subtype, type 1 VWD, $p=0.293$, and type 2 VWD, $p=0.238$. In addition, at the time of inclusion in the study, patients were asked to report bleeding symptoms experienced during the previous year that required VWD-specific treatment. There was no difference in reported bleeding symptoms between older and younger type 1 VWD patients, $23 \%$ versus $30 \%, p=0.271$. In contrast, older type 2 VWD patients reported more bleeding symptoms than young patients, $59 \%$ versus $39 \%, p=0.046$. Similar to the general population, gastrointestinal bleeding was more common in older patients. In the same cohort of patients, using the selfadministered condensed MCMDM-1 VWD BAT, de Wee et al reported a 0.8 increase in bleeding score every 10 years of age. $^{23,24}$ Again, from the WiN study, using the condensed MCMDM-1 VWD BAT, Atiq et al reported a total bleeding score of 1.9 (95\% CI, 0.1-3.8) higher and more frequent bleeding events in the previous year, $29.2 \%$ versus $18.4 \%$, $p=0.030$, among type 1 VWD patients with comorbid 
Table 2 Effect of age on bleeding symptoms in von Willebrand disease

\begin{tabular}{|c|c|c|c|}
\hline Study type & Author & Patient population & Results \\
\hline $\begin{array}{l}\text { Prospective } \\
\text { cohort study }\end{array}$ & $\begin{array}{l}\text { Tosetto et al } \\
\text { Italy }\end{array}$ & $\begin{array}{l}91 \text { index cases (ICs) and } 273 \text { affected } \\
\text { family members (AFMs) with a historical } \\
\text { diagnosis of type } 1 \text { VWD and } 295 \text { unaf- } \\
\text { fected family members (UFMs) and } 195 \\
\text { controls } \\
\text { Mean age } 40 \text { years (range } 1-80 \text { ) in index } \\
\text { cases and } 32 \text { years (range } 2-91 \text { ) in affected } \\
\text { family members } \\
\text { Mean age } 41 \text { years (range } 3-90 \text { ) in unaf- } \\
\text { fected family members and } 40 \text { years } \\
\text { (range } 8-78 \text { ) in controls }\end{array}$ & $\begin{array}{l}\text { Trend for increasing bleeding score with } \\
\text { age in IC and AFM, but not UFM or controls } \\
\text { using the expert administered MCMDM-1 } \\
\text { VWD BAT at the time of diagnosis } \\
\text { Strong inverse relationship between } \\
\text { bleeding score and VWF levels, } p<0.001\end{array}$ \\
\hline \multirow[t]{4}{*}{$\begin{array}{l}\text { Cross-sectional } \\
\text { study }\end{array}$} & $\begin{array}{l}\text { Flood et al } \\
\text { United States }\end{array}$ & $\begin{array}{l}310 \text { patients with a historical diagnosis of } \\
\text { type } 1 \text { VWD }\end{array}$ & $\begin{array}{l}\text { No correlation between VWF:Ag levels and } \\
\text { bleeding score, although } 24 \% \text { of patients } \\
\text { had a normal bleeding score, } \\
\text { using the expert administered ISTH BAT }\end{array}$ \\
\hline & $\begin{array}{l}\text { Sanders et al } \\
\text { Netherlands }\end{array}$ & $\begin{array}{l}664 \text { patients with moderate to severe VWD } \\
\text { (historical VWF:Ag level and/or VWF:RCo } \\
\text { activity less than } 0.30 \mathrm{IU} / \mathrm{mL} \text { ) } \\
\text { Mean age } 71 \text { years (range } 65-85 \text { ) in } \\
\text { patients } 65 \text { years of age and older and } \\
43 \text { years (range } 16-64 \text { ) in patients less } \\
\text { than } 65 \text { years of age }\end{array}$ & $\begin{array}{l}\text { No difference in the median bleeding score } \\
\text { among } 71 \text { VWD patients } 65 \text { years of age } \\
\text { and older (older patients) compared with } \\
593 \text { VWD patients less than } 65 \text { years of age } \\
\text { (younger patients), } 12 \text { versus } 11 \text {, } \\
p=0.154 \text {, and no difference in the median } \\
\text { bleeding score between the two groups } \\
\text { according to VWD subtype, type } 1 \text { VWD, } \\
p=0.293 \text {, and type } 2 \text { VWD, } p=0.238 \\
\text { No difference in reported bleeding symp- } \\
\text { toms in previous year between older and } \\
\text { younger type } 1 \text { VWD patients, } 23 \text { vs. } 30 \% \text {, } \\
p=0.271 \\
\text { Reported bleeding symptoms in previous } \\
\text { year was greater in older type } 2 \text { VWD } \\
\text { patients compared with younger patients, } \\
59 \text { vs. } 39 \%, p=0.046\end{array}$ \\
\hline & $\begin{array}{l}\text { de Wee et al } \\
\text { Netherlands }\end{array}$ & $\begin{array}{l}664 \text { patients with moderate to severe VWD } \\
\text { (historical VWF:Ag level and/or VWF:RCo } \\
\text { activity less than } 0.30 \mathrm{IU} / \mathrm{mL} \text { ) } \\
\text { Median age } 44 \text { years (range 16-85) in } \\
\text { males and } 46 \text { years (range 16-83) in } \\
\text { females }\end{array}$ & $\begin{array}{l}0.8 \text { increase in bleeding score every } \\
10 \text { years of age using the self-administered } \\
\text { condensed MCMDM- } 1 \text { VWD BAT }\end{array}$ \\
\hline & $\begin{array}{l}\text { Atiq et al } \\
\text { Netherlands }\end{array}$ & $\begin{array}{l}333 \text { patients with type } 1 \\
\text { Mean age } 47 \pm 15 \text { years }\end{array}$ & $\begin{array}{l}\text { Bleeding score } 1.9(95 \% \mathrm{Cl}, 0.1-3.8) \text { higher } \\
\text { and more frequent bleeding events in the } \\
\text { previous year, } 29.2 \text { vs. } 18.4 \%, p=0.030 \text {, } \\
\text { among type } 1 \text { VWD patients with comor- } \\
\text { bid illnesses }\end{array}$ \\
\hline
\end{tabular}

Abbreviations: BAT, bleeding assessment tool; Cl, confidence interval; ISTH, International Society on Thrombosis and Haemostasis; MCMDM-1, molecular and clinical markers for the diagnosis and management of type 1; VWD, von Willebrand disease; VWF:Ag, von Willebrand factor:antigen; VWF:RCo, von Willebrand factor:ristocetin cofactor.

illnesses. ${ }^{17}$ These differences were not seen in patients with type 2 VWD.

Based on the above studies, it appears bleeding symptoms are not lessened with age, and in fact, may worsen; however, certain study-specific limitations, which may affect the validity of these findings, require further discussion. First, none of the studies investigated, as their first objective, the effect of age on bleeding symptoms in patients with type 1 VWD. Second, BAT administration may not have accurately reflected current bleeding risk due to the cumulative score effect. For example, a patient may have had a significant number of bleeding symptoms in early adulthood corresponding to a high bleeding score; however, even if bleeding manifestations lessen, or completely resolve with age, the bleeding score will remain unchanged. This may prevent a proper assessment of the patient's current bleeding phenotype. Lastly, comorbidities, such as liver disease, kidney disease, malignancy, etc., occur with increased incidence in older adults and affect non-VWDrelated bleeding risk; thus, they may serve as potential confounders. It is not surprising that patients with comorbid illnesses experienced more frequent bleeding, regardless of VWF:Ag level, in the Atiq et al study. ${ }^{16}$ To counter some of these limitations, our group performed a retrospective cohort study of 43 patients with an institutional diagnosis of type 1 VWD. ${ }^{25}$ No specific VWF level was identified for inclusion in the study. VWF levels and the condensed MCMDM-1 BATwere performed 
during routine clinic visits. The bleeding score was determined as an interim BAT, based on bleeding symptoms present during the prior 3 years, rather than lifelong. There was no association between VWF levels and age; however, the mean VWF:Ag level was $0.83 \pm 0.37 \mathrm{IU} / \mathrm{mL}$, and the mean VWF:RCo activity was $0.59 \pm 0.34 \mathrm{IU} / \mathrm{mL}$. This may have been confounded by the fact that $34 \%$ of patients were receiving estrogen containing hormonal therapy. The bleeding score was found to be inversely associated with age. The bleeding score decreased 0.080 , $p<0.01$, per year of life. Comorbidities were not assessed.

\section{Clinical Vignette Conclusion}

Based on the patient's recent lack of bleeding symptoms, current normal VWF levels, and cardiovascular risk factors, periprocedural VWD-specific therapy was omitted. The patient underwent an uncomplicated laparoscopic sigmoid colectomy. Postoperative pharmacologic venous thromboprophylaxis was not recommended. The patient experienced no bleeding or thrombotic events. The patient was recommended to have VWF levels checked prior to future invasive procedures to determine the need for VWD-specific therapy on a case-by-case decision.

\section{Conclusion}

Based on the current state of the literature, VWF levels increase with age in patients with "low VWF" and type 1 VWD, thus may be more likely to occur in patients without a pathogenic VWF mutation, and may be the consequence of comorbid illnesses. Whether normalization of VWF levels results in amelioration of bleeding symptoms is uncertain. In the case we present, it appears at least some patients as they age may tolerate invasive procedures without VWD-specific therapy. Whether with age, a new "supernormal" VWF level is necessary for hemostasis, and if so, what the value is, remains unclear. The current findings are conflicting, possibly due to study-specific differences, patient-specific characteristics, primary study objectives, method of BAT administration, and confounding due to comorbid illnesses.

Determining whether or not bleeding risk is reduced in aging type 1 VWD patients is essential to providing hematologists the knowledge needed to deliver appropriate medical care to affected patients. Aging patients commonly undergo invasive procedures. If older type 1 VWD patients have experienced normalization of VWF levels, and no longer have an increased risk of bleeding, administration of VWDspecific therapy may be harmful, especially among patients with underlying cardiovascular disease or related risk factors, and unnecessarily costly. For these reasons, further investigation into the effect of age on VWF levels and bleeding risk in VWD patients is sorely needed. Ideally, large, multicenter cross-sectional or prospective observational studies of type 1 VWD patients measuring current bleeding symptoms while accounting for non-VWD-related bleeding risks are desired, and our institution will be leading a multicenter, cross-sectional study to begin this task.

\section{Authors' Contributions}

C.D.S. and M.V.R. researched the topic, analyzed the data, formulated the conclusions, and wrote the paper.

\section{Funding}

This study was funded by the University of Pittsburgh Cancer Institute.

\section{Conflict of Interest}

M.V.R. reports grants and other from Alnylam/Sanofi, Biomarin, Bioverativ and SPARK, and grants from Sangamo, during the conduct of the study. C.D.S. reports personal fees from Bayer, Takeda, Spark Therapeutics, Genentech, outside the submitted work.

\section{References}

1 Lillicrap D. von Willebrand disease: advances in pathogenetic understanding, diagnosis, and therapy. Blood 2013;122(23): $3735-3740$

2 Leebeek FWG, Eikenboom JCJ. von Willebrand's disease. N Engl J Med 2016;375(21):2067-2080

3 Tosetto A, Castaman G, Rodeghiero F. Bleeding scores in inherited bleeding disorders: clinical or research tools? Haemophilia 2008; 14(03):415-422

4 World Federation of Hemophilia. Compendium of assessment tools. Available at: https://elearning.wfh.org/resource/compendium-of-assessment-tools/\#bleeding_assessment_tools1a42-60 ce78a1-2573f205-9a34. Accessed May 10, 2020

5 Nichols WL. The Diagnosis, Evaluation, and Management of von Willebrand Disease. Bethesda, MD: National Heart, Lung, and Blood Institute; 2007. NIH Pub. No. 08-5832

6 Favaloro EJ, Franchini M, Lippi G. Aging hemostasis: changes to laboratory markers of hemostasis as we age - a narrative review. Semin Thromb Hemost 2014;40(06):621-633

7 Kawecki C, Lenting PJ, Denis CV. von Willebrand factor and inflammation. J Thromb Haemost 2017;15(07):1285-1294

8 Coppola R, Mari D, Lattuada A, Franceschi C. von Willebrand factor in Italian centenarians. Haematologica 2003;88(01):39-43

9 Kadir RA, Economides DL, Sabin CA, Owens D, Lee CA. Variations in coagulation factors in women: effects of age, ethnicity, menstrual cycle and combined oral contraceptive. Thromb Haemost 1999;82(05):1456-1461

10 Albánez S, Ogiwara K, Michels A, et al. Aging and ABO blood type influence von Willebrand factor and factor VIII levels through interrelated mechanisms. J Thromb Haemost 2016;14(05):953-963

11 Higgins RA, Goodwin AJ. Automated assays for von Willebrand factor activity. Am J Hematol 2019;94(04):496-503

12 Rydz N, Grabell J, Lillicrap D, James PD. Changes in von Willebrand factor level and von Willebrand activity with age in type 1 von Willebrand disease. Haemophilia 2015;21(05):636-641

13 Abou-Ismail MY, Ogunbayo GO, Secic M, Kouides PA. Outgrowing the laboratory diagnosis of type 1 von Willebrand disease: a two decade study. Am J Hematol 2018;93(02):232-237

14 Borghi M, Guglielmini G, Mezzasoma AM, et al. Increase of von Willebrand factor with aging in type 1 von Willebrand disease: fact or fiction? Haematologica 2017;102(11):e431-e433

15 Sanders YV, Giezenaar MA, Laros-van Gorkom BA, et al; WiN study group. von Willebrand disease and aging: an evolving phenotype. J Thromb Haemost 2014;12(07):1066-1075

16 Flood VH, Christopherson PA, Gill JC, et al. Clinical and laboratory variability in a cohort of patients diagnosed with type 1 VWD in the United States. Blood 2016;127(20):2481-2488

17 Atiq F, Meijer K, Eikenboom J, et al; WiN study group. Comorbidities associated with higher von Willebrand factor (VWF) levels 
may explain the age-related increase of VWF in von Willebrand disease. Br J Haematol 2018;182(01):93-105

18 James PD, Notley C, Hegadorn C, et al. The mutational spectrum of type 1 von Willebrand disease: results from a Canadian cohort study. Blood 2007;109(01):145-154

19 Goodeve A, Eikenboom J, Castaman G, et al. Phenotype and genotype of a cohort of families historically diagnosed with type 1 von Willebrand disease in the European study, Molecular and Clinical Markers for the Diagnosis and Management of Type 1 von Willebrand Disease (MCMDM-1VWD). Blood 2007;109(01):112-121

20 Swystun LL, Lillicrap D. Genetic regulation of plasma von Willebrand factor levels in health and disease. J Thromb Haemost 2018; 16(12):2375-2390

21 Miesbach W, Berntorp E. When von Willebrand disease comes into age - a matter of change? Eur J Haematol 2011;86(06):496-501
22 Tosetto A, Rodeghiero F, Castaman G, et al. A quantitative analysis of bleeding symptoms in type 1 von Willebrand disease: results from a multicenter European study (MCMDM-1 VWD). J Thromb Haemost 2006;4(04):766-773

23 de Wee EM, Sanders YV, Mauser-Bunschoten EP, et al; WiN study group. Determinants of bleeding phenotype in adult patients with moderate or severe von Willebrand disease. Thromb Haemost 2012;108(04):683-692

24 Bowman M, Mundell G, Grabell J, et al. Generation and validation of the Condensed MCMDM-1VWD Bleeding Questionnaire for von Willebrand disease. J Thromb Haemost 2008;6(12): 2062-2066

25 Seaman CD, Ragni MV. The association of aging with von Willebrand factor levels and bleeding risk in type 1 von Willebrand disease. Clin Appl Thromb Hemost 2018;24(03):434-438 